\title{
EVALUASI PELAYANAN VAKSIN COVID - 19 (STUDI KASUS PUSKESMAS MOJO KOTA SURABAYA)
}

\author{
${ }^{1}$ Maharani Ulya Fadhilah, ${ }^{2}$ Umi Fauziyah, ${ }^{3}$ Adellia Ammertia Cahyani, ${ }^{4}$ Lukman Arif \\ 1,2,3,4 Program Studi Administrasi Publik Fakultas IImu Sosial dan Ilmu Politik \\ Universitas Pembangunan Nasional (UPN) Veteran Jawa Timur \\ Email: ariflukman208@gmail.com \\ Surabaya, 60294, Indonesia
}

\begin{abstract}
During the COVID-19 pandemic, cases of the increase in positive patients in Indonesia were getting out of control and increasing in number, therefore the Government is ready for a vaccine that will be given in stages according to the priority of the recipient as an effort to tackle the spread of COVID-19 transmission. Vaccination can be carried out in health agencies such as in Puskesmas. The purpose of this research was to evaluate the quality of service in the implementation of the COVID-19 vaccination at Puskesmas Mojo Surabaya. The research method used is a qualitative approach with descriptive methods. The data technique used was observation, interview, and documentation study and then analyzed using an interactive data analysis model. The results of this study are the quality of the COVID19 vaccination service at Puskesmas Mojo Surabaya based on the dimensions of public service Tangibles, Reliability, Responsiveness, Assurance, and Emphaty. Applicable in the process of vaccination services at Puskesmas Mojo Surabaya on complicated online data collection and scheduling, because not all of the facilities and population data are available where there have never been residents who have moved, therefore the result is a long queve to update the data. The quality of vaccine services at Puskesmas Mojo Surabaya is satisfactory in terms of facilities, services, and resources and it is necessary to make efforts to schedule and collect data more regularly to overcome service process constraints.
\end{abstract}

Keywords: Public service; Service Quality; Vaccinations

\begin{abstract}
Abstrak
Di masa pandemi COVID-19 ini kasus pelonjakan pasien positif di Indonesia semakin tidak terkendali dan bertambah banyak, maka dari itu Pemerintah sudah menyiapkan vaksin yang akan diberikan secara bertahap sesuai prioritas penerima sebagai upaya untuk menanggulangi penyebaran penularan COVID-19. Pelaksanaan vaksinasi dapat dilakukan di Instansi Kesehatan seperti di Puskesmas. Tujuan dari penelitian ini adalah untuk mengevaluasi kualitas pelayanan dalam pelaksanaan vaksinasi COVID-19 di Puskesmas Mojo Kota Surabaya. Metode penelitian yang digunakan adalah pendekatan kualitatif dengan metode deskriptif. Teknik pengumpulan data dengan melakukan observasi, wawancara, dan studi dokumentasi kemudian dianalisis dengan menggunakan model analisis data interaktif. Hasil penelitian ini mengevaluasi kualitas pelayanan vaksinasi COVID-19 di Puskesmas Mojo Kota Surabaya berdasarkan dimensi-dimensi pelayanan publik Tangibles, Reliability, Responsiveness, Assurance, dan Emphaty. Terdapat kendala dalam proses pelayanan vaksinasi di Puskesmas Mojo Kota Surabaya pada pendataan dan penjadwalan secara online yang rumit, karena tidak semua tersedia fasilitasnya dan data kependudukan belum diperbarui apabila ada penduduk yang pindah, maka dari itu akibat yang terjadi kerumunan antrian yang panjang untuk memperbarui datanya. Kualitas pelayanan vaksin di Puskesmas Mojo Kota Surabaya memuaskan dari sisi fasilitas, pelayanan, dan sumber daya serta perlu diupayakan penjadwalan dan pendataan yang lebih teratur untuk mengatasi kendala proses pelayanan.
\end{abstract}

\section{Keywords: Kualitas Pelayanan; Pelayanan Publik; Vaksinasi}

Open Access at:http://ojs.uho.ac.id/index.php/PUBLICUHO/index Journal Publicuho is licensed under a Creative Commons Attribution 4.0 International License. 


\section{Journal Publicuho}

ISSN2621-1351 (online), ISSN 2685-0729 (print)

Volume 4 Number 2 (May-July), (2021)pp. 536-552

Accredited SINTA SK.NOMOR 28/E/KPT/2019

Open Access at:http://ojs.uho.ac.id/index.php/PUBLICUHO/index

DOI: 10.35817/jpu.v4i2.18095

\section{PENDAHULUAN}

Pelayanan publik merupakan suatu tolok ukur kinerja Pemerintah yang paling umum. Masyarakat dapat menilai langsung kinerja Pemerintah berdasarkan pelayanan yang diterima, maka dari itu pelayanan publik di semua Kementrian / Lembaga adalah suatu hal yang sangat mendasar. Berdasarkan Undang-Undang Nomor 25 Tahun 2009 Tentang Pelayanan Publik disebutkan bahwa pelayanan prima adalah pelayanan yang cepat, mudah, pasti, murah dan akuntabel. Dalam pelayanan sektor publik menjadi suatu keharusan mewujudkan pelayanan prima yang harus dipenuhi oleh pemerintah untuk membuat ketersediaan pelayanan publik yang mudah, terjangkau, dan merata. Kualitas pelayanan publik harus ditingkatkan dan dipenuhi agar pelayanan publik mampu melayani masyarakat dengan optimal. Pelayanan publik tak terkecuali dari pelayanan kesehatan yang memadai bagi masyarakat luas. Pelayanan publik menjadi isu kebijakan yang sangat strategis dari tahun ke tahun, karena perbaikan pelayanan publik di Indonesia cenderung berjalan di tempat sampai saat ini, tidak terlihat perubahan yang signifikan dan berarti diikuti oleh masih banyaknya keluhan dari masyarakat sebagai penerima layanan. Sementara itu, implementasi dari bidang kesehatan ini sangatlah luas pada semua bidang, baik itu dalam kehidupan ekonomi, politik, sosial dan budaya (Inayati and Widiyarta 2018)

Pelayanan kesehatan merupakan kebutuhan dasar bagi semua orang. Pelayanan Kesehatan menjadi tanggung jawab besar bagi Pemerintah Daerah untuk menyediakan layanan kesehatan yang berkualitas dan dapat dimanfaatkan oleh seluruh lapisan masyarakat, selain itu pelayanan kesehatan yang tidak berbelit-belit memudahkan setiap orang untuk mendapatkan pelayanan. Pemerintah Daerah berkewajiban memenuhi kebutuhan pelayanan kesehatan yang memadai dan mudah dijangkau oleh seluruh lapisan masyarakat. Pelayanan dasar kesehatan itu meliputi lingkungan yang sehat, pencegahan penyakit, peningkatan jumlah dan mutu tenaga kesehatan, ketersediaan dan keterjangkavan obat, perbaikan gizi masyarakat, pelayanan kesehatan perorangan dan masyarakat, pembiayaan kesehatan masyarakat dan pemberdayaan individu, keluarga dan masyarakat untuk berperilaku sehat. Pelayanan dasar kesehatan ini terutama menjadi tanggung jawab setiap penyedia layanan kesehatan Puskesmas yang ada di Kecamatan karena Puskesmas ini merupakan lembaga kesehatan yang paling dekat dengan masyarakat (Widiyarta and $N, 2016$ ). Untuk meningkatkan pelayanan kesehatan yang optimal diwujudkan melalui Puskesmas untuk memudahkan pelayanan kesehatan hingga ke lingkungan terkecil di masyarakat. Puskesmas adalah unit pelaksana teknis Dinas Kesehatan Kabupaten/Kota yang bertanggung jawab menyelenggarakan pembangunan kesehatan disuatu wilayah kerja (Kemenkes 2004). Puskesmas diharapkan mampu memberikan pelayanan kesehatan dasar serta menjadi pelopor penggerak pembangunan di wilayah 
kerjanya. Kesehatan merupakan hal yang paling penting dalam masyarakat. Kesehatan merupakan salah satu hal yang mendasar untuk kesejahteraan masyarakat yang harus diwujudkan sesuai cita - cita bangsa Indonesia itu sendiri yang tertuang dalam Pembukaan UUD Tahun 1945. Maka dari itu, perlu adanya layanan kesehatan yang memadahi, kompatibel, dan mampu dijangkau oleh seluruh lapisan masyarakat.

Di masa pandemi saat ini tentunya kualitas pelayanan kesehatan harus ditingkatkan sesuai dengan protokol kesehatan untuk mengurangi laju kasus positif COVID-19 di Indonesia. Puskesmas sebagai penyedia layanan kesehatan berperan penting khususnya sebagai pelaksana vaksinasi COVID-19 dituntut untuk memberikan pelayanan yang bermutu dari segi manajemen pelayanan kesehatan, fasilitas kesehatan yang memadai, dan sumber daya untuk meningkatkan kualitas pelayanan kesehatan guna memberikan kepuasan kepada pengguna jasa Puskesmas. Perlu adanya standar pelayanan kesehatan yang menjadi patokan pelayanan untuk mewujudkan kualitas pelayanan, dalam hal ini standar pelayanan kesehatan vaksinasi COVID-19 sesuai dengan protokol kesehatan. Keberadaan standar dalam pelayanan kesehatan akan memberikan manfaat, antara lain mengurangi variasi proses, persyaratan profesi bagi pegawai, dan dasar untuk mengukur mutu. Ditetapkannya standar juga akan menjamin keselamatan pasien dan petugas penyedia pelayanan kesehatan (Machmud, 2008). Serta menerapkan protokol kesehatan dengan menjaga jarak atau physical distancing dan melengkapi diri dengan alat pelindung diri selama proses pelayanan vaksinasi.

Berdasarkan PMK No 84 Tahun 2020 pengertian vaksin adalah produk biologi yang berisi antigen berupa mikroorganisme yang sudah mati atau masih hidup yang dilemahkan, masih utuh atau bagiannya, atau berupa toksin mikroorganisme yang telah diolah menjadi toksoid atau protein rekombinan, yang ditambahkan dengan zat lainnya, yang bila diberikan kepada seseorang akan menimbulkan kekebalan spesifik secara aktif terhadap penyakit tertentu. Corona Virus Disease 2019 yang disebut COVID-19 adalah penyakit menular yang disebabkan oleh Severe Acute Respiratory Syndrom Coronavirus 2(SARS-CoV-2).

Puskesmas Mojo Kota Surabaya sebagai salah satu penyedia layanan vaksin COVID-19 menerapkan prosedur pelayanan vaksin COVID-19 berdasarkan PMK No.84 Tahun 2020 tentang Pelaksanaan Vaksinasi Dalam Rangka Penanggulangan Pandemi Corona Virus Disease 2019 (Covid-19) yang mengacu pada BAB V Pelaksanaan Pelayanan Vaksinasi Covid-19 sebagai dasar acuan tata pelaksanaan pelayanan vaksinasi COVID-19. Puskesmas Mojo Kota Surabaya juga memiliki 3-4 layanan percepatan vaksin di lokasi lainnya untuk memudahkan menjangkau penerima vaksin yang berdomisili jauh dari Puskesmas. Namun, di Puskesmas Mojo Kota Surabaya pelayanan vaksin Covid-19 memiliki kendala pendataan penjadwalan dan tahapan yang rumit dari pusat disebabkan pendataan jadwal dan tahapan yang diakses secara online menyulitkan proses pelayanan apabila data penerima 


\section{Journal Publicuho}

ISSN2621-1351 (online), ISSN 2685-0729 (print)

Volume 4 Number 2 (May-July), (2021)pp. 536-552

Accredited SINTA SK.NOMOR 28/E/KPT/2019

Open Access at:http://ojs.uho.ac.id/index.php/PUBLICUHO/index

DOI: 10.35817/jpu.v4i2.18095

vaksin yang ada belum diperbaruhi, sehingga mengharuskan untuk pendataan ulang dan menyebabkan kerumunan antrian yang Panjang saat proses pelayanan. Berkaitan dengan latar belakang diatas mendorong untuk dilakukan suatu penelitian Evaluasi Pelayanan Vaksin Covid-19 (Studi Kasus Puskesmas Mojo Kota Surabaya). Penelitian ini mengkaji kualitas pelayanan berdasarkan dimensi-dimensi pelayanan publik (Tangibles, Reliability, Responsiveness, Assurance, dan Emphaty). Tujuan dari penelitian ini adalah untuk mengevaluasi kualitas pelayanan dalam pelaksanaan vaksinasi Covid-19 di Puskesmas Mojo Kota Surabaya. Manfaat penelitian ini adalah dapat menjadi rujukan bagi stakeholder dalam mewujudkan pelaksanaan pelayanan vaksinasi Covid-19 yang lebih berkualitas.

\section{KAJIAN LITERATUR}

\section{Kualitas Pelayanan Kesehatan}

Pelayanan mempunyai arti sebagai yang memberikan keperluan perseorangan atau masyarakat yang mempunyai kepentingan dalam suatu organisasi sesuai dengan tata cara yang ditentukan. Pelayanan publik merupakan pemenuhan kebutuhan dalam hak dasar setiap warga negara dan penduduk untuk memperoleh pelayanan atas barang maupun jasa yang disediakan oleh penyelenggara pelayanan publik secara maksimal.

Pengertian Pelayanan Publik adalah kegiatan yang dilakukan oleh seseorang atau sekelompok orang dengan landasan faktor material melalui sistem, prosedur dan metode tertentu dalam usaha memenuhi kepentingan orang lain sesuai dengan haknya (Saputro 2016). Seperti uraian diatas, maka pelayanan publik merupakan kegiatan yang dapat dilakukan orang atau kelompok untuk memenuhi kebutuhan orang lain.

Pelayanan Publik atau pelayanan umum dapat didefinisikan sebagai segala bentuk jasa pelayanan, baik dalam bentuk barang publik maupun jasa publik yang pada prinsipnya menjadi tanggung jawab dan dilaksanakan oleh instansi pemerintah di pusat, di daerah, dan di lingkungan Badan Usaha Milik Negara atau Badan Usaha Milik Daerah, dalam upaya pemenuhan kebutuhan masyarakat maupun dalam rangka pelaksanaan ketentuan peraturan perundang-undangan (Ratminto 2005).

Menurut Dwiyanto (2006:56) yang dikutip dari La Ode Muhammad Elwan. (2019) bahwa pemberian pelayanan publik oleh aparatur pemerintah kepada masyarakat (publik) merupakan perwujudan dan fungsi aparatur negara sebagai pelayan masyarakat (abdi), disamping sebagai abdi negara. Dalam konteks ini masyarakatlah sebagai aktor utama (pelaku) pembangunan, sedangkan pemerintah berkewajiban untuk mengarahkan, membimbing serta menciptakan suasana yang menunjang kegiatan-kegiatan dari masyarakat tersebut. Pada kondisi ini aparatur negara dituntut untuk lebih mampu memperbaiki kinerjanya (pelayanan prima) dan diharapkan lebih mampu merumuskan konsep atau menciptakan iklim yang kondusif, sehingga sumber daya pembangunan dapat 
menjadi pendorong percepatan terwujudnya masyarakat yang mandiri dan sejahtera. Pelayanan yang telah menunjuk kepada aturan formal dianggap telah memenuhi sendisendi pelayanan yang baik dan aparat pelayanan dianggap telah konsisten dalam menerapkan aturan hukum pelayanan, (La Ode Muhammad Elwan, 2019)

Salah satu contoh bidang pelayanan publik adalah Pelayanan Kesehatan. Kualitas pelayanan kesehatan merupakan aspek penting bagi warga negara untuk dapat mendapatkan kesehatan yang optimal dan memadai bagi masyarakat. Pelayanan kesehatan merupakan kebutuhan dasar yang mutlak bagi penerima layanan dalam kehidupannya.

Dalam UU 36 tahun 2009 tentang Kesehatan menyatakan bahwa kesehatan adalah keadaan sehat, baik secara fisik, mental, spritual maupun sosial yang memungkinkan setiap orang untuk hidup produktif secara sosial dan ekonomis. Dan setiap orang berhak mendapatkan kesehatan. Pada tahun 2019, Peraturan Menteri Kesehatan menerbitkan tentang Standart Teknis Pemenuhan Mutu Pelayanan Dasar Pada Standart Pelayanan Minimal bidang Kesehatan, Puskesmas atau Unit Kesehatan yang diterbitkan dalam Permenkes Nomer 4 Tahun 2019. Dalam Standart Pelayanan Minimal bidang Kesehatan (SPM Kesehatan) merupakan ketentuan mengenai Jenis dan Mutu Pelayanan Dasar yang merupakan Urusan Pemerintahan Wajib yang berhak diperoleh setiap Warga Negara secara minimal. SPM Kesehatan terdiri atas SPM Kesehatan Daerah Provinsi dan SPM Kesehatan Daerah Kabupaten/Kota. Jenis pelayanan dasar pada SPM Kesehatan Daerah Provinsi terdiri atas: Pelayanan kesehatan bagi penduduk terdampak krisis kesehatan akibat bencana dan/atau berpotensi bencana provinsi sedangkan pelayanan kesehatan bagi penduduk pada kondisi kejadian luar biasa provinsi.

Pelayanan dasar pada SPM Kesehatan dilaksanakan pada fasilitas pelayanan kesehatan baik milik pemerintah pusat, pemerintah daerah, maupun swasta. Pelayanan dasar dilaksanakan oleh tenaga kesehatan sesuai dengan kompetensi dan kewenangan. Selain oleh tenaga kesehatan untuk jenis pelayanan dasar tertentu dapat dilakukan oleh kader kesehatan terlatih di luar fasilitas pelayanan kesehatan di bawah pengawasan tenaga kesehatan. Menurut Permenkes No 4 tahun 2019, capaian kinerja dalam pemenuhan mutu pelayanan setiap jenis pelayanan dasar pada SPM Kesehatan harus 100\% (seratus persen).

Undang - Undang Nomor 36 Tahun 2009 Tentang Kesehatan juga mengatur hal - hal mengenai pelayanan kesehatan yang terdiri dari:

a. Pelayanan kesehatan promotif adalah suatu kegiatan dan/atau serangkaian kegiatan pelayanan kesehatan yang lebih mengutamakan kegiatan yang bersifat promosi kesehatan.

b. Pelayanan Kesehatan Preventif adalah suatu kegiatan pencegahan terhadap suatu masalah kesehatan/penyakit. 


\section{Journal Publicuho}

ISSN2621-1351 (online), ISSN 2685-0729 (print)

Volume 4 Number 2 (May-July), (2021)pp. 536-552

Accredited SINTA SK.NOMOR 28/E/KPT/2019

Open Access at:http://ojs.uho.ac.id/index.php/PUBLICUHO/index DOI: 10.35817/jpu.v4i2.18095

c. Pelayanan Kesehatan Kuratif adalah suatu kegiatan dan/atau serangkaian kegiatan pengobatan yang ditujukan untuk penyembuhan penyakit, pengurangan penderitaan akibat penyakit, pengendalian penyakit, atau pengendalian kecacatan agar kualitas penderita dapat terjaga seoptimal mungkin.

d. Pelayanan Kesehatan Rehabilitatif adalah kegiatan dan/ atau serangkaian kegiatan untuk mengembalikan bekas penderita ke dalam masyarakat sehingga dapat berfungsi lagi sebagai anggota masyarakat yang berguna untuk dirinya dan masyarakat semaksimal mungkin sesuai dengan kemampuannya.

e. Pelayanan Kesehatan Tradisional adalah pengobatan dan/atau perawatan dengan cara dan obat yang mengacu pada pengalaman dan keterampilan turun temurun secara empiris yang dapat dipertanggungjawabkan dan diterapkan sesuai dengan norma yang berlaku di masyarakat.

Dasar untuk menilai kualitas layanan terus berubah dan berbeda. Apa yang dipandang sebagai kualitas layanan saat ini bukan tidak mungkin dipandang sebagai sesuatu yang tidak ada di waktu lain. Oleh karena itu, sangat sulit untuk mencapai kesepakatan tentang kualitas. Kualitas merupakan keistimewaan dalam produk barang atau jasa yang dapat memenuhi kebutuhan. Seringkali beranggapan kualitas itu suatu sarana yang memuaskan pelanggan dengan kebutuhan yang sesuai. Peningkatan kualitas pelayanan kesehatan merupakan suatu upaya untuk meningkatkan kualitas dan inovasi pelayanan kesehatan di instansi pemerintah secara berkala sesuai kebutuhan dan harapan masyarakat. Di sisi lain peningkatan kualitas pelayanan dilakukan untuk membangun kepercayaan masyarakat terhadap pelayanan kesehatan yang ada guna meningkatkan kesejahteraan masyarakat setempat (Aminullah and Setyasih 2021). Membangun kualiatas layanan itu memang bukan hal yang mudah, banyak hal yang harus disikapi dengan positif untuk pengembangan pelayanan itu sendiri kedepannya.

Untuk mengidentifikasi kepuasan pelanggan, dapat melakukan survei pada pelanggan sesuai dengan dimensi - dimensi pada kualitas pelayanan. Dengan demikian, untuk dapat menilai kualitas pelayanan publik itu sendiri dapat dianalisis dari kriteria dimensidimensi kualitas pelayanan publik. Menurut Parasuraman dan Zeithaml dalam (Hardiyansyah $2011: 46-47)$ kualitas pelayanan dapat diukur dari 5 dimensi, yaitu:

a. Tangibel (Berwujud) adalah bentuk nyata pelayanan yang diterima oleh pemberi jasa seperti fasilitas fisik yang tersedia dan penampilan fisik pegawai layanan.

b. Reliability (Kehandalan) adalah kemampuan suatu layanan untuk memberikan pelayanan yang sesuai dengan yang dijanjikan, seperti penghargaan yang diraih dan sumber daya manusia yang professional 
c. Responsiviness (Ketanggapan) adalah kemampuan suatu layanan untuk memberikan pelayanan yang tanggap dan tepat kepada pelanggan dengan memberikan informasi yang jelas, seperti pegawai memberikan penjelasan mengenai standart pelayanan atau kegiatan pelayanan yang mendetail dan dapat dimengerti oleh penerima layanan.

d. Assurance (Jaminan) adalah jaminan pegawai yang dapat memberikan pelayanan untuk dapat menumbuhkan rasa percaya kepada penerima layanan, seperti pegawai memberikan pelayanan secara sungguh - sungguh untuk memuaskan penerima layanan.

e. Empathy (Empati) adalah kemampuan suatu layanan untuk memberikan pelayanan yang perhatian yang tulus untuk memahami keinginan penerima layanan, seperti sikap pegawai yang mamu memahami penerima layanan dengan penuh simpatik dan perhatian.

Kualitas pelayanan kesehatan sangat ditentukan oleh kebutuhan pasien yang bisa terpenuhi dan diterima tepat waktu, sehingga penyedia jasa pelayanan kesehatan harus mampu memenuhi harapan pasien. Dua hal yang mempengaruhi kualitas jasa pelayanan adalah expected services dan perceived services. Jasa pelayanan kesehatan dikatakan berkualitas dan dapat meningkatkan kepuasan pengguna jasa pelayanan jika perceived service sesuai dengan expected services (Muis, 2017). Maka dari itu, Pelayanan kesehatan dapat mengukur kualitas pelayanan yang ada pada pasien dengan adanya umpan balik apa yang diterima sehingga pelayanan kesehatan tersebut akan mendapatkan masukan untuk peningkatan kualitas pelayanan.

\section{Kebijakan Pelayanan Vaksinasi Covid-19}

Menurut Peraturan Presiden Republik Indonesia Nomor 99 Tahun 2020 tentang Pengadaan Vaksin dan Pelaksanaan Vaksinasi dan Penanggulangan Pandemi Corona Virus Disease 2019 (COVID-19) Pasal 1 bahwa dalam rangka percepatan penanggulangan pandemic Corona Virus Disease 2019 (COVID-19), pemerintah melakukan percepatan pengadaan Vaksin COVID-19 dan pelaksanaan Vaksinasi COVID-19. Cakupan pelaksanaan pengadaan Vaksin dan pelaksanaan Vaksinasi COVID-19 meliputi:

a. Pengadaan Vaksin COVID-19

b. Pelaksanaan Vaksinasi COVID-19

C. Pendanaan pengadaan Vaksin COVID-19 dan pelaksanaan Vaksinasi COVID-19 dan

d. Dukungan dan fasilitas Kementrian, Lembaga, dan Pemerintah Daerah.

Dalam Pasal 3 Pengadaan Vaksin COVID-19 ini meliputi: penyediaan Vaksin COVID-19 dan peralatan pendukung dan logisitik yang diperlukan dan distribusi Vaksin COVID-19 sampai pada titik serah yang ditetapkan oleh Menteri Kesehatan. 


\section{Journal Publicuho}

ISSN2621-1351 (online), ISSN 2685-0729 (print)

Volume 4 Number 2 (May-July), (2021)pp. 536-552

Accredited SINTA SK.NOMOR 28/E/KPT/2019

Open Access at:http://ojs.uho.ac.id/index.php/PUBLICUHO/index

DOI: 10.35817/jpu.v4i2.18095

Peralatan pendukung mencakup syringe, kapas alkohol, alat pelindung diri untuk menerapkan protokol kesehatan (fase shield, hazmat, sarung tangan dan masker bedah), cold chain, cadangan sumber daya listrik (genset), tempat sampah limbah bahan berbahaya dan beracun (safety box), dan cairan antiseptic berbahan dasar alkohol. Kementrian Kesehatan dalam pelaksanaan Vaksinasi COVID-19 menetapkan:

a. Kriteria dan prioritas penerima vaksin

b. Prioritas wilayah penerima vaksin

c. Jadwal dan tahapan pemberian vaksin

d. Standart pelayanan vaksinasi.

Pasal 14 menyatakan bahwa Kementrian Kesehatan dalam pelaksanaan Vaksin COVID-19 dapat bekerjasama dengan Kementrian / Lembaga, Pemerintah Daerah Provinsi, Pemerintah Daerah Kabupaten / Kota, Badan Usaha Milik Negara atau Badan Usaha SWASTA, Organisasi Profesi / Kemasyarakatan dan pihak lainnya. Kerjasama ini meliputi dukungan penyediaan tenaga Kesehatan, tempat vaksinasi, logistik / transportasi, gudang dan alat penyimpanan vaksin termasuk buffer persediaan / stock piling, sosialisasi dan penggerakan masyarakat.

Berdasarkan PMK No 84 Tahun 2020 tentang Pelaksanaan Vaksinasi Dalam Rangka Penanggulangan Pandemi Corona Virus Disease 2019 (COVID-19) tertuang dalam Bab V menjelaskan mengenai Pelaksanaan Pelayanan Vaksinasi COVID-19 bahwa jadwal dan tahapan pemberian Vaksin COVID-19 ditetapkan sesuai dengan ketersediaan Vaksin COVID-19, kelompok prioritas penerima Vaksin COVID-19 dan jenis Vaksin COVID-19. Pelayanan Vaksinasi COVID-19 dilaksanakan di Fasilitas Pelayanan Kesehatan milik Pemerintah Pusat, Pemerintah Daerah, atau masyarakat/swasta, yang memenuhi persyaratan. Fasilitas Pelayanan Kesehatan berupa: Puskesmas, Puskemas pembantu, dan Pos Pelayanan Vaksinasi COVID-19, Klinik, Rumah Sakit dan Unit Pelayanan Kesehatan di Kantor Kesehatan Pelabuhan. Untuk persyaratan fasilitas pelayanan kesehatan menurut Pasal 17 adalah:

a. Memiliki tenaga kesehatan pelaksana Vaksinasi COVID-19

b. Memiliki sarana rantai dingin sesuai dengan jenis Vaksin COVID-19 yang digunakan atau sesuai dengan ketentuan peraturan perundang-undangan

c. Memiliki izin operasional Fasilitas Pelayanan Kesehatan atau penetapan oleh Menteri sesuai dengan ketentuan peraturan perundang-undangan.

Pemenuhan fasilitas ini harus bekerja sama atau berkoordinasi dengan Puskesmas atau Dinas Kesehatan Provinsi / Kabupaten / Kota. Fasilitas dalam melaksanakan pelayanan Vaksinasi COVID - 19 menurut Pasal 23, membentuk tim pelaksana yang memiliki fungsi:

a. Pendaftaran 
b. Skrining (anamnesa), pemeriksaan fisik dan pemberian edukasi, serta persetujuan tindakan

c. Penyiapan dan pemberian Vaksin COVID-19

d. Melakukan observasi pasca Vaksinasi COVID-19, pemberian tanda selesai Vaksinasi COVID-19, dan pemberian sertifikat Vaksinasi COVID-19

e. Melakukan pencatatan dan input data hasil Vaksinasi COVID-19

f. Melakukan pengelolaan limbah medis

g. Mengatur alur kelancaran pelayanan Vaksinasi COVID-19.

Pemberian Vaksin COVID - 19 harus dilakukan oleh dokter, bidan, atau perawat yang memiliki kompetensi dan kewenangan sesuai peraturan perundang-undangan. Sarana dan prasana dalam pelaksanaan Vaksinasi COVID-19 meliputi gudang dan sarana rantai dingin Vaksin COVID-19 serta peralatan pendukung dan logistik. Gudang dan sarana rantai dingin Vaksin COVID-19 harus memiliki sertifikat cara distribusi obat yang baik atau instalasi farmasi pemerintah. Peralatan pendukung dan logistik juga mencakup dalam pelaksanaan ini. Selain peralatan pendukung dan logistik dalam pelaksanaan Vaksinasi COVID-19 didukung dengan fasilitas cuci tangan dan alat pemadam api ringan (APAR).

Tata laksana pelayanan Vaksinasi COVID-19 mengacu pada standar pelayanan, dan standar prosedur operasional yang ditetapkan oleh masing-masing pimpinan Fasilitas Pelayanan Kesehatan sesuai dengan petunjuk teknis pelaksanaan vaksinasi. Setiap orang yang telah diberikan Vaksin COVID-19 diberikan surat keterangan Vaksin COVID-19 berupa kartu Vaksinasi COVID-19 atau sertifikat elektronik.

Sesuai dalam kajian teori yang terdapat dalam PMK No. 84 Tahun 2020 tentang Pelaksanaan Vaksinasi Dalam Rangka Penanggulangan Pandemi Corona Virus Disease 2019 (COVID-19) tertuang dalam Bab V menjelaskan mengenai Pelaksanaan Pelayanan Vaksinasi COVID-19. Dalam penelitian ini yang akan dikaji dalam hasil dan pembahasan yaitu mengenai segi fasilitas yang tersedia serta penampilan fisik pegawai pelayanan vaksin, kebersihan dan kelengkapan fasilitas vaksin dan ruangan, kemampuan dan ketanggapan para pegawai pelayanan vaksin dalam memahami aspirasi dan kebutuhan penerima vaksin. Penelitian ini juga membahas mengenai standar proses pelaksanaan vaksin maupun tata pelaksanaan vaksin. Serta perilaku dan perhatian yang diberikan para pegawai pelayanan kesehatan vaksin COVID-19 kepada penerima vaksin.

\section{METODOLOGI}

Penelitian ini menggunakan Pendekatan Kualitatif Deskriptif. Menurut (Sugiyono 2012) Penelitian Kualitatif Deskriptif adalah metode penelitian yang berlandaskan pada filsafat postpositivisme yang biasanya digunakan untuk meneliti pada kondisi objektif yang alamiah dimana peneliti berperan sebagai instrument kunci. Metode ini menyajikan secara langsung hakikat hubungan antar peneliti dan informan, objek dan subjek penelitian. 


\section{Journal Publicuho}

ISSN2621-1351 (online), ISSN 2685-0729 (print)

Volume 4 Number 2 (May-July), (2021)pp. 536-552

Accredited SINTA SK.NOMOR 28/E/KPT/2019

Open Access at:http://ojs.uho.ac.id/index.php/PUBLICUHO/index DOI: 10.35817/jpu.v4i2.18095

Penelitian ini dilakukan di Puskesmas Mojo Kota Surabaya, karena merupakan salah satu kawasan perkotaan yang memiliki tingkat pertumbuhan penduduk yang sangat tinggi, serta memiliki kondisi fisik dasar yang berpotensi sebagai tempat pemukiman. Puskesmas Mojo yang berada di Kelurahan Mojo sendiri pada saat bulan Oktober 2020 memiliki kasus COVID-19 terbanyak No.1 dari 10 Kelurahan di Surabaya. Wawancara dalam penelitian dilakukan secara terbuka terhadap informan yang dipilih dengan menggunakan tehnik purposive sampling untuk memperoleh key person. Teknik pengumpulan data penelitian ini menggunakan observasi, wawancara, dan dokumen kemudian dianalisis dengan menggunakan model analisis data interaktif dari Miles and Huberman dalam (H.B. Sutopo. 2002:96). Tahap analisis data yang dilakukan dengan cara: 1) reduksi data yaitu memilah data primer dan data sekunder ke dalam bagian yang sesuai, 2) penyajian data yaitu menyusun data ke dalam kalimat yang berguna untuk menjelaskan hasil penelitian, data yang sesuai pembahasan kemudian disusun secara sistematis dalam paragraph, tabel, serta bagan yang dapat mempermudah pembaca dalam memahami hasil penelitian, 3) penarikan kesimpulan dan verifikasi yaitu mengambil kesimpulan dari data yang telah ditampilkan.

\section{HASIL DAN PEMBAHASAN}

Kualitas pelayanan yang digunakan peneliti untuk analisis dalam penelitian ini adalah menggunakan analisis kualitas pelayanan yang dikemukakan oleh Parasuraman dan Zeithaml dalam (Hardiyansyah 2011). Kualitas Pelayanan dapat diukur dari 5 dimensi, yaitu:

\section{Tangibles (Bukti langsung)}

Tangibles (Bukti Langsung) pada pelayanan vaksinasi COVID-19 di Puskesmas Mojo Kota Surabaya yang berkaitan dengan hal-hal yang bersifat fisik yang ada di Puskesmas Mojo Kota Surabaya yang dapat mendukung penyelenggara pelayanan kesehatan vaksinasi COVID-19 yang di berikan oleh para pegawai pelayanan vaksin COVID-19 kepada para penerima vaksin yang dapat diamati atau dilihat langsung dari segi fasilitas yang tersedia dan penampilan fisik para pegawai pelayanan vaksin. Serta bukti langsung dapat diamati dari kebersihan dan kelengkapan fasilitas vaksin dan ruangan.

Para pegawai pelayanan vaksinasi dalam melakukan pelayanan vaksin COVID-19 semua dilibatkan, begitu juga dalam proses pemberian vaksin COVID-19 semua tenaga kesehatan pelaksana vaksin dilibatkan, yakni para dokter, bidan, atau perawat yang memiliki kompetensi dan kewenangan sesuai dengan ketentuan peraturan perundangundangan. Penampilan pegawai pelayanan vaksin sudah lengkap sesuai prosedur protokol kesehatan dengan menggunakan alat pelindung diri (masker medis, face shield, hazmat, dan sarung tangan), terdapat kelengkapan dalam fasilitas pelayanan yang meliputi gudang dan sarana rantai dingin sesuai dengan jenis vaksin COVID-19 yang digunakan, dan juga 
tersedia peralatan pendukung dan logistik seperti kapas, alkohol, tempat sampah limbah bahan berbahaya dan beracun (safety box), dan cairan antiseptik yang berbahan dasar alkohol. Serta dalam pelayanan vaksin COVID-19 didukung dengan fasilitas cuci tangan dan alat pemadam kebakaran ringan (APAR).

Penampilan pegawai pelayanan vaksin yang sudah lengkap menerapkan protokol kesehatan dengan memakai alat pelindung diri merupakan hal yang sangat berpengaruh besar dalam pelaksanaan vaksin, untuk mencegah penularan melalui kontak fisik. Pegawai pelayanan vaksin menggunakan alat pelindung diri yang sesuai dengan ketentuan yang telah ditetapkan dalam Permenkes. Pegawai pelayanan vaksin memaksimalkan perlengkapannya demi terwujudnya pelayanan yang berkualitas sehingga penerima vaksin dapat menerima vaksin dengan nyaman.

\section{Reliability (Kehandalan)}

Kehandalan dalam kualitas pelayanan vaksin COVID-19 di Puskesmas Mojo Kota Surabaya yakni kemampuan para pegawai pelayanan vaksin dalam menyelenggarakan pelayanan vaksin COVID-19 harus sesuai yang dijanjikan kepada masyarakat secara akurat yang sesuai dengan standar mutu dan sumber daya manusia yang sudah ditetapkan dan diharapkan oleh masyarakat para penerima vaksinasi COVID-19. Kehandalan ini dapat diukur dari indikator seperti kemampuan ataupun sumber daya manusia yang terkait, sasaran para pegawai dalam menunjang kualitas pelayanan, serta ketelitian dan kesabaran para pegawai pelayanan vaksin.

Pada pelayanan vaksin untuk para penerima vaksin perlu mendapatkan perhatian yang lebih serius terutama yang berkaitan dengan SDM (Sumber Daya Manusia) yang berkeja pada instansi di Puskesmas. Pegawai pelayanan vaksin di Puskesmas Mojo Kota Surabaya sudah sesuai dengan indikator kompetensi SDM (Sumber Daya Manusia) yang merupakan pengetahuan yang berhubungan dengan pekerjaan pada bidangnya masingmasing yang menyangkut tugas dan tanggung jawabnya dalam bekerja, berkaitan dengan pengaturan, prosedur, teknik yang baru dalam pelayanan, serta untuk mengetahui bagaimana menggunakan informasi, peralatan dan teknik yang tepat dan benar. SDM (Sumber Daya Manusia) di Puskesmas Mojo Kota Surabaya untuk menunjang terlaksananya program pelayanan vaksinasi dengan menjangkau sasaran utamanya melalui kualitas kinerja pegawai pelayanan vaksin untuk meningkatkan kualitas pelayanan pada Puskesmas Mojo Kota Surabaya.

Pada sumber daya manusia meliputi pegawai pelayanan vaksin termasuk tenaga kesehatan pelayanan vaksin dan penjaga di Puskesmas Mojo Kota Surabaya. Pegawai pelayanan vaksin dan penjaga sangat profesional dan disiplin, yakni para pegawai pelayanan vaksin dan penjaga memiliki kinerja yang handal dan berperilaku baik dalam melayani penerima vaksin, karena seluruh pegawai pelayanan vaksin dan penjaga 


\section{Journal Publicuho}

ISSN2621-1351 (online), ISSN 2685-0729 (print)

Volume 4 Number 2 (May-July), (2021)pp. 536-552

Accredited SINTA SK.NOMOR 28/E/KPT/2019

Open Access at:http://ojs.uho.ac.id/index.php/PUBLICUHO/index DOI: 10.35817/jpu.v4i2.18095

Puskesmas Mojo Kota Surabaya memiliki tanggung jawab yang penuh dalam menyelenggarakan tugas yang sesuai dengan bidang masing-masing dan berdasarkan prosedur pelayanan. Tingkat kedisiplinan dan kesigapan pegawai pelayanan vaksin dalam melayani penerima vaksin di Puskesmas Mojo Kota Surabaya sudah sangat disiplin dengan bukti para pegawai pelayanan vaksin datang tepat waktu sesuai jam kerja dan tidak meninggalkan pekerjaan selama jam kerja. Disiplin merupakan hal yang dibutuhkan dalam proses pelayanan, karena merupakan persyaratan penting dalam pembentukan sikap dan perilaku. Dengan begitu pelayanan tersebut akan dapat menciptakan suasana kerja yang kondusif dan mendukung.

Pegawai pelayanan vaksin di Puskesmas Mojo Kota Surabaya juga teliti dalam melayani proses pelayanan, karena ketelitian pegawai merupakan proses yang sangat penting saat melakukan proses pelayanan. Jika para pegawai tidak teliti saat melakukan pelayanan maka akan terjadi kesalahan dan keterlambatan yang dapat menimbulkan pekerjaan baru yang seharusnya tidak dilakukan oleh pegawai, dan akan menimbulkan penilaian yang kurang baik dari penerima layanan terhadap kualitas pelayanan yang diberikan.

Pegawai pelayanan vaksin juga profesional dan berkompeten dalam melakukan pelayanan mulai dari penerapan protokol kesehatan di lingkungan Puskesmas, pendataan penjadwalan dan tahapan, proses vaksinasi, hingga observasi kondisi gejala atau efek yang ditimbulkan pada penerima vaksin setelah vaksinasi. Dengan begitu pegawai pelayanan vaksin harus professional dan berkompeten khususnya yang terjun langsung dengan pelayanan agar tercipta pelayanan yang baik dan penerima vaksin tersebut juga akan memberi penilaian yang baik dan memuaskan.

Dalam konteks pelayanan vaksin COVID-19 di Puskesmas Mojo Kota Surabaya bahwa kemampuan pegawai pelayanan vaksin di Puskesmas Mojo Kota Surabaya untuk menyelenggarakan pelayanan vaksinasi yang dijanjikan kepada para penerima vaksin secara akurat dan sesuai dengan standar mutu yang telah ditetapkan dan diharapkan oleh penerima vaksin. Dimensi reliability dapat dilihat dari indikator seperti kemauan dan kejujuran pegawai pelayanan vaksin dalam memberikan layanan, kecepatan pegawai penerima vaksin dalam memberikan proses layanan kepada para penerima vaksin yang dilayani, keadilan pegawai pelayanan vaksin dalam memberikan layanan kepada setiap penerima vaksin dalam pelaksanaan layanan vaksin COVID-19 di Puskesmas Mojo Kota Surabaya.

\section{Responsiveness (Daya tanggap)}

Responsiveness (daya tanggap) dalam konteks layanan kesehatan vaksinasi di Puskesmas Mojo Kota Surabaya berkaitan dengan tingkat ketanggapan pegawai pelayanan vaksin dalam memahami aspirasi dan kebutuhan penerima vaksin yang dilayani serta memberikan 
respon atas aspirasi dan kebutuhan tersebut. Dimensi responsiveness dapat dilihat dari kemampuan pegawai pelayanan vaksin dalam pelayanan vaksinasi untuk cepat tanggap dalam menghadapi masalah yang timbul dari layanan kesehatan vaksinasi yang diberikan, kemampuan pegawai pelayanan vaksin cepat tanggap menyelesaikan keluhan atau efek dari vaksin yang diberikan kepada penerima vaksin, dan kemampuan pegawai pelayanan vaksin dalam pemberian layanan vaksin sangat membantu memenuhi kebutuhan penerima vaksin.

Sikap tanggap yang diberikan oleh penyedia layanan kesehatan vaksin COVID-19 menjadi salah satu hal yang terpenting dalam penyelenggaraan pelayanan kesehatan yang berkualitas. Daya tanggap pegawai pelayanan vaksin sangat bagus dapat dilihat pada pengaturan jadwal dan pendataan, penyampaian informasi yang jelas, dan juga pelaksanaan pelayanan sesuai prosedur. Pengaturan jadwal dan tahapan dalam pemberian vaksin COVID-19 yang ditetapkan dan prioritas penerima vaksin COVID-19 tergantung data yang sudah ada, dalam hal ini yang menjadi prioritas pertama adalah lansia. Proses pendataan vaksin COVID-19 terdapat surat dari Dinas Kesehatan, penerima vaksin untuk lansia yang sudah di data oleh Puskesmas kemudian diserahkan ke Kecamatan atau Kelurahan. Jika sudah di proses maka selanjutnya turun ke RT. Setelah tahapan ini, maka lansia akan mendapatkan undangan untuk proses vaksinasi COVID-19. Pegawai pelayanan vaksin di Puskesmas Mojo Kota Surabaya menyampaikan informasi yang jelas dan mendetail mengenai standart pelayanan vaksinasi agar dapat dimengerti dan dipahami oleh penerima vaksin dengan komunikasi yang baik, serta membantu penerima vaksin dalam proses pelayanan vaksinasi. Hal tersebut penting dilakukan untuk mengupayakan minim complain pelayanan, apabila terjadi sesuatu yang mendesak akan dilakukan rapat kecil oleh pegawai pelayanan vaksin bersama Kepala Puskesmas untuk mengambil keputusan penyelesaian masalah. Pelaksanaan pelayanan vaksin COVID-19 di Puskesmas Mojo Kota Surabaya telah sesuai standar operasional prosedur (SOP). Bagian awal yang meliputi pendataan dan pendaftaran, menunggu antrian, setelah itu screening, lalu proses vaksinasi, setelah proses vaksinasi terdapat bagian akhir yang meliputi obervasi selama 30 menit untuk mengecek kondisi para penerima vaksin COVID-19 terkait gelaja atau efek yang ditimbulkan dari vaksinasi tersebut. Selain itu, pegawai pelayanan vaksin memberikan pemahaman pentingnya vaksinasi COVID-19 untuk menanggulangi penyebaran COVID-19.

Pelaksanaan pelayanan vaksin COVID-19 di Puskesmas Mojo Kota Surabaya telah sesuai dengan standar operasional prosedur (SOP). Maka dari itu dalam memiliki standar pelayanan kesehatan yang sesuai dalam pelayanan tersebut memang sangat penting karena proses pelayanan dapat berjalan dengan baik guna mencapai tujuan pelaksanaan pelayanan vaksin COVID-19 ini. 


\section{Journal Publicuho}

ISSN2621-1351 (online), ISSN 2685-0729 (print)

Volume 4 Number 2 (May-July), (2021)pp. 536-552

Accredited SINTA SK.NOMOR 28/E/KPT/2019

Open Access at:http://ojs.uho.ac.id/index.php/PUBLICUHO/index DOI: 10.35817/jpu.v4i2.18095

Pegawai pelayanan vaksin juga membantu dalam merespon penerima vaksin yang datang. Penerima vaksin tersebut akan sangat terbantu dan merasa dihargai oleh pegawai pelayanan vaksin ketika pegawai pelayanan vaksin tersebut dapat memberikan respon yang baik. Dengan adanya respon yang baik ini maka dapat menimbulkan efek positif bagi kualitas pelayanan tersebut. Dibuktikan dengan menerapkan protokol kesehatan yang mewajibkan para penerima vaksin untuk memakai masker sebelum memasuki Puskesmas, setelah itu melakukan screening cek suhu, penerima vaksin tersebut akan diarahakan untuk melakukan cuci tangan terlebih dahulu, kemudian pegawai pelayanan vaksin tersebut akan mengarahkan penerima vaksin untuk mengantri dengan tertib dan menjaga jarak menuju meja pendaftaran untuk pengecekan pendataan. Dengan begitu penerima vaksin tersebut akan senang dan sangat terbantu apabila pegawai pelayanan vaksin memberi respon atau tanggap dengan keperluan yang dibutuhkan. Maka dari itu, akan menjadikan penilaian yang sangat memuaskan bagi kualitas pelayanan tersebut.

\section{Assurance (Jaminan)}

Jaminan pada Puskesmas Mojo Kota Surabaya dapat dilihat dari standar proses pelaksanaan maupun tata pelaksanaan, dapat juga dilihat dari proses pendaftaran, serta layanan vaksin Puskesmas Mojo Kota Surabaya memberikan kepastian fasilitas atau jaminan kartu vaksin dihari itu juga. Jaminan yang diberikan oleh Puskesmas Mojo Kota Surabaya ini berupa tata pelaksanaan vaksin yang sesuai dengan PMK No.84 Tahun 2021 yang berkaitan dengan pendataan jadwal dan tahapan, standar pelayanan, sarana dan prasarana, dan prosedur pelayanan. Tata pelaksanaan pelayanan vaksin COVID-19 mengacu pada standar operasional prosedur yang ditetapkan oleh Pimpinan Puskesmas sesuai petunjuk pola teknis pelayanan vaksinasi. Adapun output yang diterima para pasien vaksinasi yaitu mendapatkan kartu vaksinasi atau kartu sertifikat vaksinasi dalam hari itu juga sebagai bukti telah mendapatkan vaksin. Terkait pengaturan pendataan jadwal dan tahapan dalam pemberian vaksin COVID-19 yang ditetapkan dan prioritas penerima vaksin COVID-19 ditetapkan oleh Menteri.

Pendataan jadwal dan tahapan tersedia secara online. Pada pendataan jadwal dan tahapan secara online sangat rumit, karena tidak semua penyedia layanan tersedia fasilitasnya dan data kependudukan para penerima vaksin belum diperbarui apabila ada penduduk yang pindah. Bukti empiris bahwa insfrasrtuktur kita belum siap, dan memasukkan data-data penduduk yang akurat juga belum siap. Maka dari itu jika mengandalkan online, nomor kependudukan atau penduduk yang sudah pindah tempat juga tidak diketahui, sehingga akan memperbarui data lagi. Maka untuk menunjang kualitas pelayanan vaksin COVID-19 yang perlu diperbaiki dari segi pelayanan pada saat proses pendataan online yang begitu rumit untuk menyiapkan data manual sebagai antisipasi pencocokan data 
penerima vaksin, sehingga tidak mengakibatkan terjadi kerumunan yang disebabkan oleh antrian panjang untuk mengecek ulang data pada saat pelayanan vaksinasi, sehingga para pegawai pelayanan vaksin dalam menangani pelayanan vaksin COVID-19 tidak mengalami kerepotan. Pegawai pelayanan vaksin di Puskesmas Mojo Kota Surabaya terus mengupayakan pendataan jadwal dan tahapan vaksin dengan sangat baik untuk meningkatkan kualitas pelayanan.

Pada dasarnya tersedianya pendatan secara online memudahkan pengaturan jadwal dan tahapan pelayanan vaksin COVID-19 karena dengan memanfaatkan teknologi dapat mempercepat dan mempermudah proses pelyanan vaksinasi dengan efektif dan efisien. Selain itu, pendataan secara online memudahkan semua orang untuk mengakses dan menulusuri databasenya tanpa harus mengecek secara manual. Namun, tidak semua memiliki fasilitas yang mendukung untuk memudahkan mengakses databasenya. Sehingga mengakibatkan miss informasi apabila ada data penerima vaksin yang belum diperbaruhi. Maka dari itu, penting untuk melakukan pendataan secara offline juga untuk mengantisipasi kekeliruan pendataan dan memperbaruhi data. Seperti halnya yang dilakukan Puskesmas Mojo Kota Surabaya yang melakukan pendataan online dan manual melalui Kecamatan atau Kelurahan untuk memastikan data.

\section{Emphaty (Empati)}

Empati dalam konteks layanan kesehatan vaksin COVID-19 di Puskesmas Mojo Kota Surabaya yang berkaitan dengan perilaku dan perhatian yang diberikan para pegawai pelayanan kesehatan vaksin COVID-19 kepada penerima vaksin yang dilayani, sehingga terciptanya suasana yang harmonis dan saling mengerti antara pihak yang melayani pelayanan vaksin COVID-19 dan para penerima vaksin yang dilayani. Empati dapat dilihat dari keramahan dan simpati pegawai pelayanan vaksin dalam proses layanan vaksin COVID-19.

Empati yang ditonjolkan tenaga kesehatan pelaksana vaksinasi COVID-19 kepada penerima vaksin sangat baik. Pegawai pelayanan vaksinasi memberikan rasa empati pelayanan dengan penuh simpatik dan perhatian. Pegawai pelayanan vaksin memberikan pelayanan dengan perhatian yang tulus, telaten, dan ramah untuk memahami keinginan dan kondisi penerima vaksin. Pelayanan vaksin di Puskesmas Mojo Kota Surabaya haruslah mempermudah masyarakat dalam memperoleh pelayanan kesehatan khususnya bagi para penerima vaksin yang akan melakukan vaksin, penerima vaksin harus dipastikan mendapatkan pelayanan yang sesuai dengan prosedur vaksinasi. Seluruh pegawai pelayanan vaksin membantu penerima vaksin selama proses vaksinasi untuk memberikan rasa aman, nyaman, dan menumbuhkan rasa percaya pentingnya mendapatkan vaksin COVID-19. 


\section{Journal Publicuho}

ISSN2621-1351 (online), ISSN 2685-0729 (print)

Volume 4 Number 2 (May-July), (2021)pp. 536-552

Accredited SINTA SK.NOMOR 28/E/KPT/2019

Open Access at:http://ojs.uho.ac.id/index.php/PUBLICUHO/index DOI: 10.35817/jpu.v4i2.18095

Sikap sopan dan santun juga dilakukan oleh pegawai pelayanan vaksin, karena dengan sikap sopan dan santun itu dilakukan maka semua penerima layanan akan menyukai pelayanan yang didalamnya banyak pegawai yang sikapnya sopan dan santun. Pegawai yang mempunyai sikap sopan dan santun maka pegawai tersebut dapat dikatakan pegawai yang tanggap dalam membantu orang lain. Sikap sopan dan santun tersebut memang sangat penting dimiliki oleh pegawai pelayanan vaksin dalam proses pelayanan vaksinasi karena penerima vaksin tersebut akan merasa puas terhadap pelayanan yang diberikan.

Pegawai pelayanan vaksin dan petugas Puskesmas tidak membeda-bedakan pelayanan sesuai dengan antrian saat melakukan pendataan pendaftaran vaksin. Sikap tidak membeda-bedakan ini maksudnya adalah ketika salah satu penerima vaksin tersebut mengenali pegawai misalnya keluarga dekat. Maka semua penerima vaksin harus dilayani dengan sama, adil, dan sesuai dengan nomor antrian yang didapat. Sikap tidak membedabedakan ini berarti pegawai pelayanan vaksin sudah melakukan pelayanan secara professional dan sesuai dengan standar. Petugas Puskesmas juga melayani dengan menghargai setiap pengguna layanan kesehatan dengan senyuman, menanyakan keperluan, lalu memberikan penjelasan dengan jelas dan berusaha agar kebutuhan para pengguna layanan kesehatan dapat terpenuhi.

\section{KESIMPULAN}

Berdasarkan hasil dan pembahan, maka dapat disimpulkan sebagai berikut:

1. Kualitas pelayanan vaksin COVID-19 di Puskesmas Mojo Kota Surabaya dapat diukur dari 5 sisi dimensi pelayanan publik menurut Parasuraman dan Zeithaml dalam (Hardiyansyah 2011). yaitu: tangible, reliability, responsiveness, assurance, dan empathy. Secara keseluruhan dapat dilihat bahwa proses pelayanan vaksinasi COVID-19 di Puskesmas Mojo Kota Surabaya sudah memuaskan dan sesuai dengan pelaksanaan pelayanan vaksinasi berdasarkan PMK No.84 Tahun 2020 tentang Pelaksanaan Vaksinasi Dalam Rangka Penanggulangan Pandemi Corona Virus Disease 2019 (Covid-19) BAB V Pelaksanaan Pelayanan Vaksinasi Covid-19. Tata pelaksanaan pelayanan vaksinasi COVID-19 sesuai dengan Standar Operasional Prosedur (SOP) vaksinasi COVID-19 yang ditetapkan oleh Pimpinan Puskesmas sesuai petunjuk pola teknis pelayanan vaksinasi yang berlaku.

2. Kualitas pelayanan Vaksin Covid-19 di Puskesmas Mojo Kota Surabaya memuaskan. Namun, memiliki kendala pendataan jadwal dan tahapan online yang rumit, karena tidak semua tersedia fasilitasnya dan data kependudukan belum diperbarui apabila ada penduduk yang pindah, akibatnya terjadi kerumunan antrian yang panjang untuk memperbarui data penerima vaksin. Perlu diupayakan pendataan penjadwalan dan 
tahapan vaksinasi yang lebih teratur dan terkondisi dalam melakukan pembaruan data sehingga tidak menimbulkan kerumunan. Menyediakan data manual untuk mencocokkan data dari Kecamatan atau Kelurahan untuk meminimalisir kekeliruan. Selain itu, tetap menerapkan protokol kesehatan bagi semua pegawai pelayanan vaksin dan penerima vaksin selama proses pelayanan.

\section{REFERENSI}

Aminullah, A., \& Setyasih, D. M. (2021). Implementasi Retribusi Daerah Pelayanan Kesehatan Di Uptd Kesehatan Puskesmas Puspo. Journal Publicuho, 4(1), 59-68. https://doi.org/10.35817/jpu.v4i1.16232

Hardiyansyah. 2011. Kualitas Pelayanan Publik Konsep, Dimensi, Indikator Dan Implementasinya. Yogyakarta: Gava Media.

H.B. Sutopo. 2002. Metodologi Penelitian Kualitatif. Surakarta: Universitas. Sebelas Maret Press.

Inayati, Anifa Rully, and Agus Widiyarta. 2018. "Penerapan Standar Pelayanan Minimal (Spm) Kesehatan Ibu Hamil Di Puskesmas Jatirogo Kecamatan Jatirogo Kabupaten Tuban." $8(1): 54-61$.

Kemenkes. 2004. "DEPKES RI." CWL Publishing Enterprises, Inc., Madison 2004:352.

La Ode Muhammad Elwan. (2019). PROBLEM BIROKRASI DALAM MENINGKATAN PELAYANAN

PUBLIK PADA SEKRETARIAT DAERAH KABUPATEN MUNA. In Copyright@2019 Journal

PUBLICUHO Faculty of Social and Political Sciences Halu Oleo University (Vol. 2).

Retrieved from http://ojs.uho.ac.id/index.php/PUBLICUHO

Machmud, Rizanda. 2008. "Manajemen Mutu Pelayanan Kesehatan." Jurnal Kesehatan Masyarakat 2(2):186-90.

Muis, Abdul. 2017. "Analisis Kualitas Pelayanan Kesehatan Di Puskesmas Kecamatan Kongbeng Kabupaten Kutai Timur." Administrasi Publik 1 (1):236-40.

Ratminto. 2005. Manajemen Pelayanan. Yogyakarta: Pustaka Pelajar.

Saputro, Harius Eko. 2016. "Kualitas Pelayanan Publik." Profesional: Jurnal Komunikasi Dan Administrasi Publik 2(1). doi: 10.37676/professional.v2i1.163.

Sugiyono. 2012. Metode Penelitian Kuantitatif, Kualitatif, Dan Tindakan. BANDUNG: ELFABETA.

Widiyarta, Agus, and Ertien Rining N. 2016. "Pelayanan Kesehatan Dari Perspektif Participatory Governance." Jurnal Dinamika Governance 6(1):23-42.

Peraturan Menteri Kesehatan Nomer 4 Tahun 2019 tentang Standart Teknis Pemenuhan Mutu Pelayanan Dasar Pada Standart Pelayanan Minimal bidang Kesehatan.

Peraturan Presiden Republik Indonesia Nomor 99 Tahun 2020 tentang Pengadaan Vaksin dan Pelaksanaan Vaksinasi dan Penanggulangan Pandemi Corona Virus Disease 2019 (COVID-19)

Peraturan Menteri Kesehatan Republik Indonesia Nomor 84 Tahun 2020 Tentang Pelaksanaan Vaksinasi Dalam Rangka Penanggulangan Pandemi Corona Virus Disease 2019 (Covid-19).

Undang-Undang Nomor 25 Tahun 2009 tentang Pelayanan Publik.

Undang - Undang 36 Tahun 2009 tentang Kesehatan. 